\title{
Comparison of Greenhouse Methods for Assessing Resistance to Bacterial Leaf Spot in Plum
}

\author{
B.L. Topp', W.B. Sherman, R.E. Stall' ${ }^{2}$ G.V. Minsavage ${ }^{2}$, and C.J. Wilcox ${ }^{3}$ \\ Fruit Crops Department, University of Florida, Gainesville, FL 32611 \\ Additional index words. Prunus salicina, Xanthomonas campestris pv. pruni, fruit breeding, inoculum, infiltration, disease \\ screening, field evaluation
}

\begin{abstract}
Four greenhouse leaf inoculation methods for screening Japanese plum (Prunus salicina L. and hybrids) for resistance to Xanthomonas campestris pv. pruni (Smith) Dye were compared for repeatability, ability to differentiate among plant genotype responses, and correlations with field ratings. Clonally propagated trees were inoculated artificially in a greenhouse by immersing leaves in $2.5 \times 108 \mathrm{cfu} / \mathrm{ml}$ inoculum (DIP), rubbing the adaxial side of leaves with a slurry of 2.5 $\times 108 \mathrm{cfu} / \mathrm{ml}$ inoculum and Carborundum powder (CARB), infiltrating leaves with $5 \times 10^{5} \mathrm{cfu} / \mathrm{ml}$ inoculum using a needleless syringe (INFS), and infiltrating with $5 \times 10^{6} \mathrm{cfu} / \mathrm{ml}$ inoculum (INF6). No greenhouse method was superior in all assessment categories. The CARB method was most repeatable $(t=0.78)$ but had a low Spearman's correlation $\left(r_{s}=0.29\right)$, indicating that greenhouse rankings did not correspond closely with field rankings. The INF6 method was unsuitable because it did not differentiate between plant genotypes. The DIP method appeared most suitable, having moderate repeatability $(t=0.46)$ for four observations per leaf and moderate Spearman's correlation with field performance $\left(r_{s}=\right.$ 0.56). The INF5 method may be appropriate for identifying bacterial spot resistance that is associated with resistance in the leaf mesophyll.
\end{abstract}

Field evaluation of fruit tree breeding germplasm is expensive due to large plant size and prolonged juvenility (Hansche, 1983). Therefore, selection methods that allow roguing of undesirable genotypes before field planting are beneficial. Resistance to bacterial diseases can be assessed in this manner, and many methods have been used on various crops. Greenhouse systems for Prunus have included immersing leaves under vacuum (Daines and Hough, 1951), infiltrating with by high pressure sprays (Civerolo and Keil, 1976; Du Plessis, 1986), and infiltrating with needleless syringe (Du Plessis, 1988; Hammerschlag, 1988; Randhawa and Civerolo, 1985). The desirability of any one system of disease inoculation and assessment depends on its accuracy, precision, and correlation with field performance. Partitioning the total variance of random variables in experiments that compare plant genotypes allows determination of some of these factors (Campbell and Madden, 1990; Gomez and Gomez, 1984). The purpose of this study was to compare four greenhouse leaf inoculation and assessment systems for Xanthomonas campestris pv. pruni on Japanese-type plums for repeatability (precision), correlation with field ratings (accuracy), and ability to differentiate among genotypes.

\section{Materials and Methods}

Plant material. Six plum genotypes were chosen at random from a large germplasm collection at Gainesville, Fla., and propagated by stem cuttings to produce from four to seven ramets per genotype. Two ramets per genotype were grown in a greenhouse in 5-liter containers of a commercial potting mix (Terra-Lite Metro-mix 200, Cambridge, Mass.) for 12 months before inoculation. The remaining rooted cuttings were field planted in a disease

Received for publication 27 Apr. 1992. Accepted for publication 20 Nov. 1992. Florida Agricultural Experiment Station journal series no. R-02344. The cost of publishing this paper was defrayed in part by the payment of page charges. Under postal regulations, this paper therefore must be hereby marked advertisement solely to indicate this fact.

'Present address: Queensland Dept. of Primary Industries, Granite Belt Horticultural Research Station, P.O. Box 501, Stanthorpe, Queensland 4380, Australia. 'Plant Pathology Dept.

${ }^{3}$ Dairy Science Dept. nursery. The disease nursery was a high-density planting (Sherman and Lyrene, 1983) with susceptible 'Gulfruby' spreader trees every $4 \mathrm{~m}$ along the interrow. Natural spread of bacterial spot was aided by artificial inoculation of spreader trees and overhead irrigation. No bactericides were applied to the disease nursery. Six additional genotypes were propagated in a similar manner for use in the correlation study, but only one potted tree of each was assessed in the greenhouse.

Inoculum preparation. A Florida isolate of $X$. campestris pv. pruni was grown overnight in Difco nutrient broth, pelleted by centrifugation, and resuspended in sterile tap water to obtain $5 \times$ $10^{8} \mathrm{cfu} / \mathrm{ml}$ by photometrically standardizing to $0.3 \mathrm{~A}$ at $600-\mu \mathrm{m}$ wavelength. These suspensions were diluted serially with sterile tap water to obtain the specified concentrations of inoculum.

Inoculation and assessment systems. All inoculations were performed in the greenhouse between 0700 and $0900 \mathrm{HR}$ when the air was at $\approx 23 \mathrm{C}$. Temperatures during the fortnight of disease development ranged from 20 to 35C. Methods were as follows:

1) DIP-The apical 10 leaves of a branch were immersed in 2.5 $\times 10^{8} \mathrm{cfu} / \mathrm{ml}$ inoculum and agitated for $5 \mathrm{sec}$ to fully wet leaf surfaces. After 14 days, the number of lesions per square centimeter of leaf area was counted at four sites selected randomly on each of the three most severely affected leaves per branch.

2) CARB-The third, fourth, and fifth leaves from the growing tip were rubbed on the adaxial side with a slurry of Carborundum powder and $2.5 \times 10^{8} \mathrm{cfu} / \mathrm{ml}$ inoculum. The number of lesions per square centimeter of leaf was counted at four sites selected randomly on the three leaves 14 days after inoculation.

3) INF5- The third, fourth, and fifth leaves from the growing tip were infiltrated with $5 \times 10^{5} \mathrm{cfu} / \mathrm{ml}$ inoculum with a needleless syringe at four sites per leaf to produce infiltrated circles $\approx 2 \mathrm{~cm}$ in diameter. The infiltrated area was not visible $1 \mathrm{~h}$ after inoculation. Disease development was assessed 14 days after inoculation by estimating the percentage of watersoaking and necrosis at each site.

4) INF6-Leaves were inoculated as described for INF5 but with $5 \times 10^{6} \mathrm{cfu} / \mathrm{ml}$ inoculum.

Experiment design and statistical analysis. In the greenhouse, all four methods were applied to each tree with one branch 
Table 1. Sources of variation, degrees of freedom (df) and expected mean squares (EMS) for analysis of the greenhouse assessment methods DIP, INF5, INF6, and CARB used to determine bacterial leaf spot resistance.

\begin{tabular}{|c|c|c|}
\hline Source $^{z}$ & df & EMS \\
\hline Genotype & 5 & $\sigma_{\mathrm{e}}^{2}+12 \sigma_{\mathrm{P}(\mathrm{G})}^{2}+24 \sigma_{\mathrm{G}}^{2}$ \\
\hline Plant $(\mathrm{G})$ & 6 & $\sigma_{e}^{2}+12 \sigma_{P(G)}^{2}$ \\
\hline Leaf position $(\mathrm{L})$ & 2 & $\sigma_{\mathrm{e}}^{\mathrm{e}^{\mathrm{e}}}+4 \sigma_{\mathrm{P}(\mathrm{G}) \times \mathrm{L}}^{2}+8 \sigma_{\mathrm{G} \times \mathrm{L}}^{2}+48 \Theta_{\mathrm{L}}^{2}$ \\
\hline $\mathrm{G} \times \mathrm{L}$ & 10 & $\sigma_{\mathrm{e}}^{2}+4 \sigma_{\mathrm{P}(\mathrm{G}) \times \mathrm{L}}^{2}+8{\sigma_{\mathrm{G} \times \mathrm{L}}^{2}}^{2}$ \\
\hline $\mathrm{P}(\mathrm{G}) \times \mathrm{L}$ & 12 & $\sigma_{\mathrm{e}}^{2}+4 \sigma_{\mathrm{P}(\mathrm{G}) \times \mathrm{L}}^{2}$ \\
\hline Error & 130 & $\sigma_{\mathrm{e}}^{2}$ \\
\hline
\end{tabular}

${ }_{\overline{\mathrm{z}}}^{\mathrm{z} \text { Abbreviations for sources of variation are } \mathrm{G}=\text { genotype, } \mathrm{L}=\text { leaf, and } \mathrm{P}}$ $=$ plant.

assigned randomly for each method. The mathematical model was $\mathrm{Y}_{\mathrm{ijkl}}=\mu+\mathrm{G}_{\mathrm{i}}+\mathrm{P}(\mathrm{G})_{\mathrm{ij}}+\mathrm{L}_{\mathrm{k}}+\mathrm{G} \times \mathrm{L}_{\mathrm{ik}}+\mathrm{P}(\mathrm{G}) \times \mathrm{L}_{\mathrm{ijk}}+\mathrm{E}_{\mathrm{ijk},}$, where $\mathrm{Y}_{\mathrm{ijkl}}$ is the disease assessment response of a single innoculation site on a leaf, $\mu$ is the overall mean, $G_{i}$ is the effect of genotype, $P(G)_{i j}$ is the effect of plant nested within genotype, $\mathrm{L}_{k}$ is the fixed effect of leaf position, $\mathrm{G} \times \mathrm{L}_{\mathrm{ik}}$ is the interaction of genotype with leaf position, $P(G) \times L_{i j k}$ is the interaction of plant nested within genotype with leaf position, and $\mathrm{E}_{\mathrm{ijk}}$ is the residual error term. All effects are random except for leaf position, which was considered fixed (Table 1). Analysis of variance and variance component estimates were obtained using the SAS GLM and VARCOMP procedures (SAS, 1987).

Repeatability was estimated using Fisher's intraclass correlation (Becker, 1984; Kempthorne, 1957), and standard errors of these variance ratios were derived as in Falconer (1989). Inspection of plots of residual vs. predicted values indicated that transformations would reduce the dependence of the variance on the mean. Data for DIP, INF5, and INF6 were transformed by $\log (\mathrm{x}+1)$ and for CARB by square root $(x+1)$ before analysis of variance.

The relationship of greenhouse methods to field ratings was obtained by Pearson's interclass correlation and Spearman's rank correlation via the SAS CORR and SAS FREQ procedures (SAS, 1987). Field ratings were taken in Aug. 1991 in a disease nursery in which each tree was inoculated with $X$. campestris pv. pruni in June 1991, and disease spread was aided by the use of susceptible trees of 'Gulfruby' planted every $4 \mathrm{~m}$ between rows of test trees. The rating scale was a modification of the 0-5 scale used by Werner et al. (1986), where $0=$ no symptoms, $1=0 \%$ to $1 \%$ of leaves with lesions, $2=>1 \%$ to $5 \%, 3=>5 \%$ to $15 \%, 4=>15 \%$ to $40 \%$, and $5=>40 \%$ of leaves with lesions. Field performance was based on the mean of two to five trees per genotype. The 0-5 ratings were converted to percentage values before calculating means based on the same reasoning that Elanco Tables are used to convert Horsfall-Barratt ratings (Campbell and Madden, 1990). Percentage values obtained in this manner were used for the Pearson's and Spearman's correlations.

\section{Results and Discussion}

Ability of the methods to detect differences among genotypes. Significant differences in mean response among the genotypes were detected by all methods except INF6, with the INF5 method providing the greatest differentiation among genotypes (Table 2). The INF6 method does not appear suitable, because it did not distinguish differences in susceptibility among the plum genotypes. INF6 resulted in $>65 \%$ watersoaking in all genotypes (Table $2)$. This failure to detect differences may be related to the high $(5$ $\times 10^{6} \mathrm{cfu} / \mathrm{ml}$ ) initial concentration of bacteria infiltrated into the leaf. At high inoculum concentration, differences in host response for susceptible and resistant genotypes can be reduced (Braun, 1982; Daub and Hagedorn, 1980). Daub and Hagedorn (1980) reported that there were almost no differences in bacterial growth rates and final bacterial populations in susceptible and resistant bean cultivars when inoculated with high concentrations $\left(10^{7}\right.$ and $10^{9} \mathrm{cfu} / \mathrm{ml}$ ) of Pseudomonas syringae $x x x x$, and yet marked differences were obtained when the leaves were inoculated with $10^{3}$ and $10^{5} \mathrm{cfu} / \mathrm{ml}$ inoculum.

Bacterial populations were measured in 'Blackamber' and C333-1, after infiltration of $5 \times 10^{5} \mathrm{cfu} / \mathrm{ml}$ inoculum into leaf mesophyll, and were found to reach high levels in both genotypes (Topp, 1992). The partial resistance found in C333-1 by the DIP, INF5 and CARB methods of disease assessment indicates that bacteria; spot symptom expression in C333-1 is low despite the high bacterial counts. This may be a form of partial resistance where an increased threshold of pathogens is required to cause infection in the host. This type of resistance has been reported in tomato (Lycopersicon esculentum Mill.), where six times as many bacterial cells were required to produce a leaf pustule in bacterial spot-resistant relative to susceptible plants (McGuire et al., 1991).

Repeatability of greenhouse methods. Repeatability partitions the total variability in the experiment into a portion that arises due to differences among the genotype groups and a portion that arises due to differences among members within each genotype group (i.e., into between group and within group components). Repeatability is a unitless variance ratio and so allows comparison of the four methods even though different units were used. Fruit breeders would like to use the inoculation and assessment system that differentiates among genotypes (maximizes $\sigma_{\mathrm{G}}^{2}$ ) but minimizes the within-genotype variance. This will be the method with highest repeatability.

Table 2. Mean genotype disease response to infection with bacterial leaf spot for various greenhouse assessment methods.

\begin{tabular}{|c|c|c|c|c|}
\hline \multirow[b]{2}{*}{ Genotype } & \multicolumn{4}{|c|}{ Greenhouse screening method ${ }^{z}$} \\
\hline & $\begin{array}{c}\text { DIP } \\
\text { (lesions } \\
\text { per } \mathrm{cm}^{2} \text { ) }\end{array}$ & $\begin{array}{c}\text { INF5 } \\
\text { (\% water- } \\
\text { soaked) }\end{array}$ & $\begin{array}{c}\text { INF6 } \\
\text { (\% water- } \\
\text { soaked) }\end{array}$ & $\begin{array}{r}\text { CARB } \\
\text { (lesions } \\
\text { per } \mathrm{cm}^{2} \text { ) }\end{array}$ \\
\hline Gulfruby & $6.38 \mathrm{a}^{\mathrm{y}}$ & $28.13 \mathrm{a}$ & $85.42 \mathrm{a}$ & $17.50 \mathrm{a}$ \\
\hline Blackamber & $5.54 \mathrm{a}$ & $22.63 \mathrm{ab}$ & $83.75 \mathrm{a}$ & $4.04 \mathrm{~b}$ \\
\hline C109-6 & $3.04 \mathrm{ab}$ & $12.75 \mathrm{bcd}$ & $65.63 \mathrm{a}$ & $2.25 \mathrm{~b}$ \\
\hline C333-2 & $1.67 \mathrm{~b}$ & $13.83 \mathrm{bc}$ & $85.29 \mathrm{a}$ & $1.21 \mathrm{~b}$ \\
\hline Cl13-5 & $0.79 \mathrm{~b}$ & $4.29 \mathrm{~cd}$ & $75.00 \mathrm{a}$ & $1.08 \mathrm{~b}$ \\
\hline C333-1 & $0.38 \mathrm{~b}$ & $1.54 \mathrm{~d}$ & 78.18 a & $0.96 \mathrm{~b}$ \\
\hline
\end{tabular}

${ }^{\mathrm{z}}$ Values are means of 24 observations per genotype ( 4 sites/leaf $\times 3$ leaves/plant $\times 2$ plants), untransformed data.

y Mean separation within columns by Duncan's multiple range test, $P \leq 0.05$. 
Table 3. Estimates of variance components, percentage of total variance (in parentheses), and repeatability for the various greenhouse assessment methods used to determine bacterial leaf spot resistance.

\begin{tabular}{|c|c|c|c|c|c|c|c|c|}
\hline \multirow{3}{*}{$\frac{\text { Source }^{z}}{\text { Genotype }}$} & \multicolumn{8}{|c|}{ Disease assessment method } \\
\hline & \multicolumn{2}{|c|}{ DIP } & \multicolumn{2}{|c|}{ INF5 } & \multicolumn{2}{|c|}{ INF6 } & \multicolumn{2}{|c|}{ CARB } \\
\hline & 0.23 & (25) & 0.79 & (39) & 0 & (0) & 1.36 & (63) \\
\hline Plant (G) & 0.13 & (14) & 0.14 & (7) & 0.02 & (30) & 0.02 & (1) \\
\hline $\mathrm{G} \times \mathrm{L}$ & 0 & $(0)^{y}$ & 0.13 & (6) & 0.00 & (9) & 0 & $(0)$ \\
\hline$P(G) \times L$ & 0 & (0) & 0.32 & (16) & 0 & (0) & 0.22 & (10) \\
\hline Error & 0.58 & (61) & 0.66 & (32) & 0.04 & (61) & 0.56 & (26) \\
\hline \multicolumn{9}{|c|}{ Repeatability $( \pm S E)$} \\
\hline 1 observation/leaf ${ }^{\mathrm{x}}$ & \multirow{2}{*}{\multicolumn{2}{|c|}{$0.24 \pm 0.14$}} & \multirow{2}{*}{\multicolumn{2}{|c|}{$\begin{array}{l}0.39 \pm 0.17 \\
0.15+0.17\end{array}$}} & \multicolumn{2}{|l|}{0.00} & \multicolumn{2}{|c|}{$0.63 \pm 0.14$} \\
\hline 4 observation/leaf ${ }^{\mathrm{w}}$ & & & & & \multicolumn{2}{|l|}{0.00} & \multicolumn{2}{|c|}{$0.78 \pm 0.21$} \\
\hline
\end{tabular}

${ }^{\mathrm{z}} \mathrm{Abbreviations}$ for sources of variation are $\mathrm{G}=$ genotype, $\mathrm{L}=$ leaf, and $\mathrm{P}=$ plant. Estimates of variance are based on transformed data.

YNegative estimates of variance set to zero.

${ }^{x}$ Repeatability for one observation per leaf $=$

$$
\begin{gathered}
\frac{\left(\sigma_{G}^{2}\right)}{\left(\sigma_{G}^{2}+\sigma_{P(G)}+\sigma_{G \times L}^{2}+\sigma_{P(G) \times L}^{2}+\sigma_{e}^{2}\right)} \\
\frac{\left(\sigma_{G}^{2}{ }_{G}\right)}{\left(\sigma_{G}^{2}+\sigma_{P(G)}+\sigma_{G \times L}^{2}+\sigma_{P(G) \times L}^{2}+\sigma^{2}{ }_{e} / 4\right.}
\end{gathered}
$$

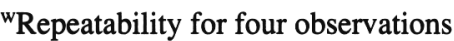
per leaf $=$

The CARB method was most repeatable, followed by INF5 and DIP (Table 3). The INF6 method had a repeatability of zero, because no variation among genotypes was detected using this method. Increasing the number of observations per leaf from one to four is recommended for the DIP and INF5 methods because of the resultant increase in repeatability. The CARB method had only $26 \%$ of total variance attributable to error (Table 3 ), and so the improvement in repeatability by increasing the number of observations per leaf was small. The plant within genotype component of variance was $<15 \%$ of total variance for three of the methods, indicating there would be little gain in increasing the number of ramets tested for each genotype (Table 3). This finding is of particular relevance as these methods eventually will be used to screen seedling populations for resistance to bacterial leaf spot, and replication of genotypes would add to the cost and time involved in testing.

Bacterial entry into the leaf by the DIP method depends on water congestion of intercellular spaces at the time of inoculation (Matthee and Daines, 1968) and on many environmental factors that influence bacterial longevity on the leaf surface (Hirano and Upper, 1983; Leben, 1974). In contrast, the infiltration methods place the bacteria into each leaf and so avoid these environmental variations. These may be reasons why DIP has a lower repeatability than INF5. However, the infiltration methods also may avoid some plant epidermal resistance mechanisms and so less closely resemble natural field infection.

Correlations of greenhouse methods with field ratings. Pearson's correlation coefficients of greenhouse and field ratings were significant for DIP and CARB but not for INF5 and INF6 (Table 4, Fig. 1). Spearman's correlation measures the correspondence of genotype rankings by the different methods, and coefficients were similar to Pearson's correlation coefficient for DIP, INF5, and INF6, but much lower for CARB (Table 4). This difference indicates that, although the overall correspondence of CARB greenhouse ratings and field ratings were relatively high, the ranking of clones in the greenhouse by the CARB method did not correspond to the ranking of clones in the field (Fig. 1B).

The DIP method had the highest correlation with field determined resistance, but a correlation of 0.69 accounts for only $48 \%$ of the variation between field and greenhouse resistance measurements. The DIP method may be used as a preliminary screen when large populations are to be reduced in the greenhouse, but some resistant seedlings would be discarded. Field testing would be required, as susceptible seedlings will be included in the selected group. For example, if the threshold were set at four lesions per square centimeter in this experiment, then two clones that average $\approx 40 \%$ leaf infection in the field would be selected using the DIP method (Fig. 1A). These would need to be culled during field screening.

The low correlations of the infiltration methods with field

Table 4. Phenotypic correlations between genotype resistance ratings for bacterial leaf spot from greenhouse assessment methods and genotype resistance ratings from the field. ${ }^{\mathrm{Z}}$

\begin{tabular}{lcc}
\hline \hline $\begin{array}{l}\text { Greenhouse } \\
\text { method }\end{array}$ & $\begin{array}{c}\text { Pearson's correlation } \\
\text { coefficient }( \pm \text { SE) }\end{array}$ & $\begin{array}{c}\text { Spearman's correlation } \\
\text { coefficient }( \pm \text { SE) }\end{array}$ \\
\hline DIP & $0.69 \pm 0.10$ & $0.56 \pm 0.25$ \\
INF5 & $0.37 \pm 0.34$ & $0.44 \pm 0.38$ \\
INF6 & $0.48 \pm 0.13$ & $0.47 \pm 0.21$ \\
CARB & $0.64 \pm 0.18$ & $0.29 \pm 0.34$
\end{tabular}

${ }^{\bar{z}}$ Genotypes tested in greenhouse and field (country/state of origin in parentheses) were: 'Blackamber' (California), 'Bruce' (Texas), 'Gulfruby' (Florida), 'Harry Pickstone' (South Africa), 'Laetitia' (South Africa), 'Wilson' (Australia); two seedling selections from U.S. Dept. of Agriculture (USDA), Fresno, Calif., two seedling selections from Univ. of Florida, Gainesville, and two seedling selections from USDA, Byron, Ga. 
A

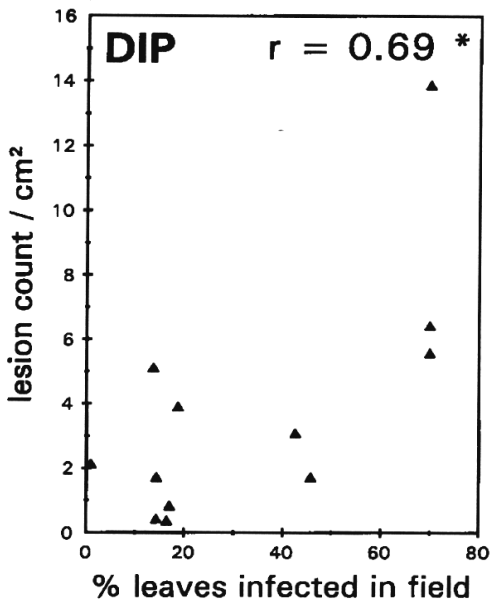

C

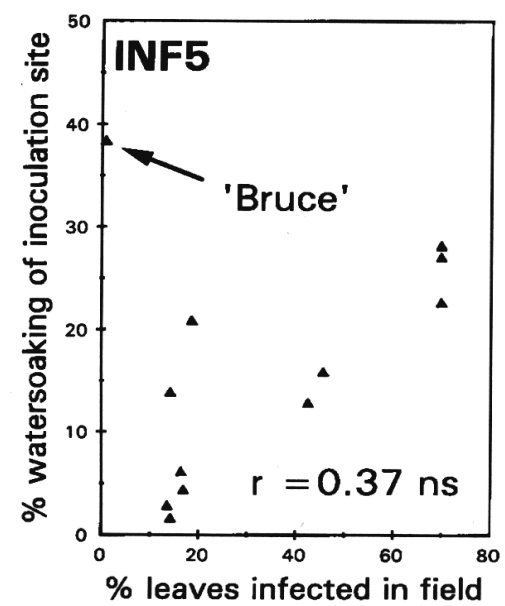

B

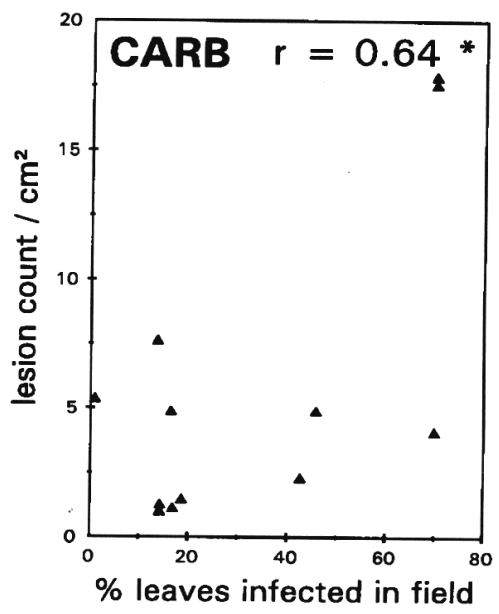

D

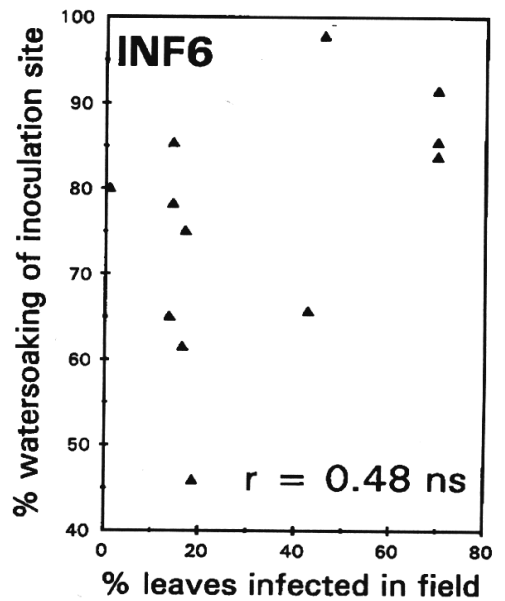

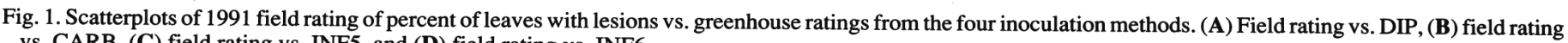
vs. CARB, (C) field rating vs. INF5, and (D) field rating vs. INF6.

ratings in this study are in contrast to the report of Randhawa and Civerolo (1983, who infiltrated detached peach [Prunus persica (L.) Batsch] leaves and reported a high degree of correspondence for 21 of the 22 peach genotypes tested, although no correlation was presented. Stall et al. (1982) noted a good correspondence between leaf infiltration and field ratings for citrus canker, but also noted that exceptions occurred. They considered these outliers the result of experimental technique, which could be overcome with improved uniformity of leaf age and with use of several inoculum doses for each plant genotype.

The sample of genotypes involved may partly explain the differences between studies. For example, if the outlier 'Bruce' in Fig. 1C is excluded from the analysis, the correlation for INF5 with field rating rises to $0.88(P=0.0004)$. Greenhouse methods that correlate to this extent with field ratings would be extremely useful.

How could 'Bruce' be resistant in the field and yet susceptible when infiltrated with $X$. campestris pv. pruni in the greenhouse? Leaf infiltrations on 'Bruce' clones in the field were repeated (data not presented) to eliminate the possibility of error such as genotype misidentification. The resistant trees in the field gave similar watersoaking percentages to those obtained on clones in the greenhouse. Another possibility is that the field disease pressure was low enough to permit escapes; this may have been a possibility in a low bacterial spot year, such as 1990, but rainfall was above average in 1991, and all four ramets of 'Bruce' rated resistant despite very high levels of bacterial spot in the disease nursery. Also, 'Bruce' has been reported field resistant in Australia (Topp et al., 1989) and in the United States (Keil and Fogle, 1974). Two other possible explanations which seem more likely are: 1) 'Bruce' has some level of epidermal resistance that results in resistant reactions in field ratings (and DIP method) but susceptible reactions with infiltration methods; and 2) 'Bruce' is exhibiting a form of partial resistance where an increased pathogen threshold is required to cause leaf spot symptoms (McGuire et al., 1991), so despite development of high bacterial concentrations in the leaf, few leaf spot symptoms develop. This could be tested by regressing bacterial population size against leaf spot development for a range of plum clones, with deviants above the curve classed as partially resistant.

Conclusions. No greenhouse screening method was clearly superior in all categories of assessment. The CARB method, 
although the most repeatable (precise), is unsatisfactory because it did not rank genotypes as they performed in the field (Spearman's correlation of $0.29 \pm 0.34$ ). The INF6 method did not distinguish differences among the genotypes, because all plants were susceptible in the mesophyll when infiltrated with $5 \times 10^{6} \mathrm{cfu} / \mathrm{ml}$ of inoculum. The DIP method appears to be the most useful of the four methods tested, with a repeatability of 0.46 for four observations per leaf. The DIP method ranked the genotypes most closely with field performance (Spearman's correlation of $0.56 \pm 0.25$ ) and detected differences among the genotypes. Field screening under severe disease pressure provides the best measure of disease resistance, but ideal test environments are not available at all locations or in all years; they also suffer the problems of high cost due to land and time commitments in assessment. For these reasons, a greenhouse method needs to be used, and the DIP method was the best of the four methods in this study. A greenhouse system that is more repeatable and correlates more highly with field results is required.

\section{Literature Cited}

Becker, W.A. 1984. Manual of quantitative genetics. 4th ed. Academic Enterprises, Pullman, Wash.

Braun, E.J. 1982. Ultrastructural investigation of resistant and susceptible maize inbreds infected with Erwinia stewartii. Phytopathology 72: 159. 166.

Campbell, C.L. and L.V. Madden. 1990. Introduction to plant disease epidemiology. Wiley, New York.

Civerolo, E.L. and H.L. Keil. 1976. Evaluation of Prunus spp. resistance to Xanthomonas pruni by artificial inoculation. Fruit Var. J. 30:17-18.

Daines, R.H. and L.F. Hough. 1951. Artificial inoculation of peach seedlings with Xanthomonas pruni. Phytopathology 41:8-9. (Abstr.)

Daub, M.E. and D.J. Hagedorn. 1980. Growth kinetics and interactions of Pseudomonas syringae with susceptible and resistant bean tissues. Phytopathology 70:429-436.

Du Plessis, H.J. 1986. Systemic migration and establishment of Xanthomonas campestris pv. pruni in plum leaves and twigs. J. Phytopathology 116:221-227.

Du Plessis, H.J. 1988. Differential virulence of Xanthomonas campestris pv. pruni to peach, plum, and apricot cultivars. Phytopathology 78:13121315.
Falconer, D.S. 1989. Introduction to quantitative genetics. 3rd ed. Wiley, New York.

Gomez, K.A. and A.A. Gomez. 1984. Statistical procedures for agricultural research. 2nd ed. Wiley, New York.

Hammerschlag, F.A. 1988. Selection of peach cells for insensitivity to culture filtrates of Xanthomonas campestris pv. pruni and regeneration of resistant plants. Theor. Appl. Genet. 76:865-869.

Hirano, S.S. and C.D. Upper. 1983. Ecology and epidemiology of foliar bacterial plant pathogens. Ann. Rev. Phytopathol. 21:243-269.

Keil, H.L. and H.W. Fogle. 1974. Orchard susceptibility of some apricot, peach and plum cultivars and selections to Xanthomonas pruni. Fruit Var. J. 28:16-19.

Kempthorne, O. 1957. An introduction to genetic statistics. Iowa State Univ. Press, Ames.

Leben, C. 1974. Survival of plant pathogenic bacteria. Ohio Agr. Res. and Dev. Ctr., Wooster, Ohio. Spec. Circ. 100.

Matthee, F.N. and R.H. Daines. 1968. Effects of soil types and substrate aeration on stomatal activity, water diffusion pressure deficit, water congestion, and bacterial infection of peach and pepper foliage. Phytopathology 58:1298-1301.

McGuire, R.G., J.B. Jones and J.W. Scott. 1991. Epiphytic populations of Xanthomonas campestris pv. vescatoria on tomato cultigens resistant and susceptible to bacterial spot. Plant Dis. 75:606-609.

Randhawa, P.S. and E.L. Civerolo. 1985. A detached-leaf bioassay for Xanthomonas campestris pv. pruni. Phytopathology 75: 1060-1063.

SAS Institute. 1987. SAS/STAT guide for personal computers, version 6 ed. SAS Inst., Cary, N.C.

Sherman, W.B. and P.M. Lyrene. 1983. Handling seedling populations, p. 66-73. In: J.N. Moore and J. Janick (eds.). Methods in fruit breeding. Purdue Univ. Press, West Lafayette, Ind.

Stall, R.E., G.M. Marco, and B.I. Canteros de Echenique. 1982. Importance of mesophyll in mature-leaf resistance to cancrosis of citrus. Phytopathology 72: 1097-1100.

Topp, B.L. 1992. Inheritance of resistance to Xanthomonas campestris pv. pruni in stems and leaves of Japanese-type plums from four breeding populations. PhD Diss., Univ. of Florida, Gainesville.

Topp, B.L., J.B. Heaton, D.M. Russell, and R. Mayer. 1989. Field susceptibility of Japanese-type plums to Xanthomonas campestris pv. pruni. Austral. J. Expt. Agr. 29:905-909.

Werner, D.J., D.F. Ritchie, D.W. Cain, and E.I. Zehr. 1986. Susceptibility of peaches and nectarines, plant introductions and other Prunus species to bacterial spot. HortScience 21:127-130. 